\title{
Мотивы древнегреческой мифологии в повести Гоголя Вий
}

\author{
СЕРГЕЙ ШУЛЬЦ \\ 3-я линия, д. 5, кв. 28, RU-344019 Ростов-на-Дону \\ E-mail: s_shulz@mail.ru
}

(Received: 4 December 2018; accepted: 4 June 2019)

Факты обращения Гоголя к образцам классических форм мифа и ритуала интересны не только сами по себе, но также в аспекте их взаимосвязи с арсеналом христианской мифологии. Принципиальным моментом здесь является то, что в свете историальной интерпретации мифа и Откровения Ф. В. Й. Шеллингом, мифология начиная с исходного своего этапа органично развивалась к христианству, к истинам Откровения (по мере исторического движения «перетекала» в них) (Шеллинг 2013).

Значению славянской мифологии для Вия посвящено немало работ (см. ИЧИРО 1989, ЛЕВКИЕВСКАЯ 1998, КИЧЕНКО 2008 и др.); МНОГО НОВОГО И цеННОГО в трактовку данной темы привнесла Л. А. Софронова (см. СофроновА 2010). Нечасто отмечались связи Вия с другими разновидностями мифологии - например, скандинавской или древнеиндийской. ${ }^{1}$ В рамках настоящей статьи будет поднят вопрос о значении для Вия древнегреческой мифологии: ее роль здесь тем более важна на фоне знаменитого античного «колорита» повести. Кроме того, по замечанию Михаила Евзлина, «для европейцев конца XVIII начала XIX вв. мифологией par excellence была мифология древнегреческая» (Евзлин 1993а: 33).

Сложная символика повести, переплетающая Эрос и Танатос, допускает параллели к мифу об Орфее и Эвридике, поскольку и в случае Вия, и в случае мифа имеет место мотив запрета на взгляд. Философ (поэт в архаическом и романтическом представлении) Хома Брут вступает в контакт с миром смерти не по своей воле, к тому же панночка-«Эвридика» погибла из-за него.

Мифологическое часто противопоставляют рациональному. Однако с рациональной точки зрения непонятно, почему в определенной ситуации нельзя оглядываться и смотреть. Ведь это, казалось бы, ничего не означающий, вполне обычный жест. Хома, оглядываясь, действует как полный рационалист - и проигрывает. Это сопоставимо с ситуацией, изображенной Э. Т. А. Гофманом в новелле Крошка Цахес по прозванию Циннобер. Крошка Цахес именно из-за отрицания его окружением мистики получает сомнительную

\footnotetext{
${ }^{1}$ Обзор этих исследований приведен в работе Шульц 1998, где поднят вопрос о соотнесенности мира Гоголя с классическим мифо-ритуальным фондом.
} 
привилегию манипулирования другими, благодаря чему добрые дела остальных людей приписываются ему, Цахесу: таким путем выражена месть феи (одна из героинь новеллы) представителям рационалистического Просвещения за их неверие в сверхчувственный мир. Но не так ли и Хома отказался внять доводам сверхчувственным, увидев в них просто предрассудок? Как известно, «предрассудки» являлись одной из мишеней со стороны просветителей.

Запрет, подобный нарушенному Хомой, ясен лишь изнутри самого мифологического сознания, его имманентной логики. Впрочем, в работах последних десятилетий миф уже редко противопоставляют логосу.

Посещение Орфеем ада приравнивало его, в христианском понимании, к Христу. В этом контексте характерно указание повествователя на то, что панночка первоначально поместила Хому на ночлег в хлев: это сопоставимо с рождением Христа в яслях. Комментируя сцену в хлеву, на возможные аллюзии искупления и жертвы (не только в христианском смысле) указала P. Собел (см. SOBEL 1979). Многие христианские параллели к сюжету и коллизиям Вия отмечены Ю. Арабовым - он говорит даже о «Голгофе» Хомы, тем самым сближая того с Христом (см. АрАБов 1998).

Мелькающее в начале гоголевской повести замечание об исполнении бурсаками в «торжественные дни и праздники» ролей «Иродиады или Пентефрии, супруги египетского царедворца» (Гоголь 2: 416) в вертепных представлениях задает дальнейший ход и словно предсказывает итог всех событий. Они развиваются в связи с косвенно намеченными в приведенном пассаже событиями испытания, подобно тому, как это выпало Иоанну Крестителю и Иосифу Прекрасному, ставшим персонажами мистерий.

Сравнение с ветхозаветным Иосифом наводит мысль также на новозаветные параллели - с учетом начального упоминания Гоголем Иоанна Крестителя и с учетом того, что в средневековой духовной драме и в так называемых «школьных» духовных драмах (как и вообе в христианстве) Иосиф Прекрасный рассматривался в качестве ветхозаветного предвестия Христа. Параллели с Иосифом Прекрасным в контексте «египетского пленения» рассмотрены в работе М. Вайскопфа (см. ВАйскоПф 1993: 150-157).

Христианский контекст возникает в Вечерах на хуторе близ Диканьки и Миргороде как позитивный идеальный фон там, где резко поляризуются этические понятия добра (сфера божественного и человеческого) и зла (сфера нечеловеческого и античеловеческого): Вечер накануне Ивана Купала, Cmpaшная месть, Вий.

В Вие ставится эксплицитный акцент на статусе Хомы как «философа», «поэта», что обращает в большей мере к фигуре античного Орфея в качестве самодостаточной. Согласно замечанию Ж. Делеза и Ф. Гваттари, «Философия, наука и искусство требуют от нас прорывать небосвод и погружаться в хаос. Только такой ценой мы сумеем его победить. Философ, ученый и художник словно возвращаются из страны мертвых» (ДЕЛЕз-ГВАТТАРИ 2009: 233). Хома в качестве школяра, студента философской ступени обучения семинарии, причастен «науке» в целом, высшим образцом каковой в средние 
века считалась теология (а философия - уже вслед за ней). Статус теолога Хома должен был получить уже на следующем курсе семинарии, но смерть обрывает такую перспективу.

Хома не победил хаос в том, что касается личной своей участи, но зато он избавил хутор, окрестности Киева от ведьмы - и уже в таком, более общем отношении он, несомненно, «победитель» всяческого хаоса. В конечном итоге эта общекоммунитарная победа становится также его индивидуальной, личной победой. Хома побывал в «царстве мертвых» во время полета с ведьмой, а затем во время ночных бдений над ее телом в церкви. Мысль В. Н. Топорова о том, что всякий побывавший в царстве мертвых - поэт (Топоров 1993: 96), еще более радикализует мнение Ж. Делеза и Ф. Гваттари, предельно расширяя статус побывавшего в потустороннем мире и границы «поэзии» (= «философии» = «науки»).

Ренессансный философ Дж. Бруно сообщает об оценке ума Орфеем следующее: «Орфей называет его [ум - С. Ш.] оком мира, ибо он наблюдает внутри и извне за всеми природными вещами, с тем чтобы все не только внутри, но и вовне производилось и содержалось в собственной соразмерности» (Бруно 1999b: 330). Орфическому «уму»-«оку» (как он описан Бруно) у Гоголя противостоит фигура Вия, который - негативное превращение «зримости» псевдоума, способной лишь губить всех неугодных и прежде всего «философов» / «поэтов», т. е. добивающихся «высшего» знания, наделенных «высшим» призванием. Псевдооко Вия разрушает «соразмерность» (если использовать терминологию Бруно) и гармонию мира.

Позднеренессансный мыслитель Ф. Бэкон трактовал фигуру Орфея в качестве «изображения философии» (Бэкон 1972: 252). Подход Бэкона мы объясним также тем, что с именем Орфея связывают религиозно-мистическое учение «орфизм»; вместе с тем Бэкон имеет в виду также метафизический потенциал самой фигуры Орфея. Гоголевский Хома - именно «метафизик», что следует трактовать символически широко.

Для такого существенного предшественника Бэкона, как Бруно, философия - предел человеческих устремлений, вершина миссии человека. Например, древность Бруно вспоминает в виде примера особого почитания философов: «Восхвалим же по достоинству древность, когда философы были таковы, что выдвигались в законодатели, советники и цари» (Бруно 1999b: 305). Философию Бруно даже приравнивал к магии, ценимую им за заданную той потенциальность проявлений высоких способностей человека (Бруно 1999а: 238). Аллегорическая трактовка мифологем в качестве жизненных смыслов и практик, предпринятая Бэконом, во многом предвосхищена еще Бруно.

У Гоголя - вероятно, начиная примерно с Вия - существует довольно устойчивый комплекс «орфических» мотивов. ${ }^{2}$ В финале Вия повествователь воспроизводит диалог между оставшимися в живых однокашниками Хомы,

${ }^{2}$ Об орфических мотивах у Гоголя см. Шульц $2017 \mathrm{~b}$. Кроме того, в гоголевском историософском этюде «Ал-Мамун», включенном в «Арабески» (цикл вышел в том же году, что и цикл «Миргород»), описана автоаллюзивная фигура жреца / философа / правителя. 
один из которых стал, подобно Хоме, «философом» и в знаменательном монологе резюмирует: «А я знаю, почему пропал он: оттого, что побоялся. А если бы не боялся, то бы ведьма ничего не могла с ним сделать» (Гоголь 2: 450).

Здесь важен даже не столько итоговый вывод о необходимости отказа от страха (вывод карнавальный и ренессансный по содержанию), сколько статус адресанта высказывания. В финале Гоголь утверждает торжество «философии» как архаического в истоках вида мыслительной деятельности, соотнесенного с мистическим веданием тайн, с «магизмом», с искусством как бесстрашным мыслительным проникновением в загадки мировой жизни. Страх и бесстрашие - это не столько эмоционально-волевые качества, сколько некие не зависящие от внешних причин состояния сознания, установки мышления, только благодаря которым совершаются все акты бытия в мире. В Bue страх оказывается актом небытия, воли к небытию. Появление в финале нового «философа» утверждает карнавальную победу длящейся жизни, пафос ее обновления и бесстрашного приращения.

«Вина» Хомы (факт, что он обернулся и посмотрел на Вия) заставляет искать параллель к нему не только в Орфее, но также в соотнесенных с его фигурой и причастных, как и он, дионисийскому культу, других героях. Речь идет, в частности, об Аристее и его сыне Актеоне. Ведь античная Эвридика погибла по вине пытавшегося вступить с ней в контакт Аристея (ГРЕйвС 1992: $213)$ - ср. с тем фактом, что у Гоголя инициатором знакомства выступает не панночка-ведьма (та вначале отнекивается и отказывает в приеме), а Хома и его компания.

Аристей - фигура, чья примечательность в контексте циклов Вечера на хуторе близ Диканьки и Миргород задана имплицитно. Аристей - прорицатель, врачеватель, пчеловод, научивший людей разводить пчел (ср. образ пасечника Рудого Панька в Вечерах, ассоциируемого с занятиями пчеловодством и медоварением - см. Шульц 2000), предмет поклонения в Аркадии, где сохранились нравы золотого века (ГРЕйвс 1992: 212-215, МНМ 1: 103-104).

После того, как по вине Аристея умерла Эвридика, его пчелы погибли, но затем, в результате жертвенных даров героя, воскресли. Его сын Актеон был превращен в оленя и растерзан собаками за то, что, согласно одной из версий мифа, пытался совершить над покровительницей Аркадии Артемидой насилие и подглядывал за ней, когда та купалась (ГРейвс 1992: 60, 82). Здесь важен мотив запретного смотрения - ср. насилие над панночкой, к которому вынужден прибегнуть Хома в целях самозащиты.

Поскольку Актеон причастен дионисийским таинствам, его гибель проецируется на гибель умирающего и воскресающего бога. Налицо имплицитная топика воскрешения жизни, прошедшей через смерть - мистическая, карнавально-эсхатологическая. В случае Хомы она не реализована в пределах фабулы.

По поводу Актеонова «перевоплощения» Хомы уместно привести замечание Дж. Бруно: «...c этими Актеонами часто бывает так: пока они преследуют диких оленей, собственные Дианы обращают их в домашних оленей 
посредством магического обряда» (Бруно 1999а: 246). Панночка с помощью своей магии пытается именно «приручить» Хому-«Актеона»- в дурном смысле, т. е. поставить себе на службу.

Вий сравним со слепым Амуром (Купидоном), особенно в трактовке Дж. Бруно: «Ибо я вовсе не желаю, чтобы Купидон открыл свои очи: он слепой стреляет так метко и попадает во всякого, а что, по-вашему, станет, если у него будут зоркие глаза?» (Бруно 1999а: 246). Образ Вия-«Купидона» трактован Гоголем отрицательно. «Замыкая» личность Хомы на эротическотанатологическом внимании его к панночке, Вий-«Купидон» и стоящие за ним мрачные силы губят героя.

По оригинальному наблюдению В. Н. Ильина, Вий - «эрос», его образом выражен «жизненный ужас эроса»; кроме того, «Вий с железным лицом и веками до земли, т. е. с качеством невозможности „рассмотреть“, увидеть, понять человека с его высокими, человеческими устремлениями и лишь с возможностью его убить» (Ильин 2000: 258, 262). Отрицательная трактовка Вия-«Купидона» Гоголем становится возможна также за счет сближения того с Танатосом, за счет раскрытия скрытого потенциала самого эроса в одном из его инфернальных воплощений. Именно от идеи мрачного воплощения эроса В. Н. Ильин протянул нить к любовным коллизиям «Анны Карениной» Л. Н. Толстого.

Страшный взгляд Вия и самой панночки, безусловно, напоминает об умерщвляющем взгляде Медузы Горгоны, заставлявшем все живое окаменевать - ср. постоянный, принципиальный для Гоголя мотив окаменения. Возникает также ассоциация с библейским повествованием о том, как жена Лота, оглянувшись, превратилась в мертвый соляной столб.

Победил Медузу герой-полубог Персей: «В мифе о Горгонах отразилась тема борьбы олимпийских богов и их героического потомства с хтоническими силами» (МНМ 1: 316). Последнее обстоятельство корреспондирует борьбе с хтоническим Вием - который «весь был в черной земле» (ГоГоль 2: 448) - «философа» Хомы. В сцене полета Хомы с ведьмой в открывающемся ему видении сцеплены ураническое и хтоническое: «Обращенный месячный серп светлел на небе. Робкое полночное сияние, как сквозное покрывало, ложилось легко и дымилось на земле. Леса, луга, небо, долины - всё, казалось, как будто спало с открытыми глазами. Ветер хоть бы раз вспорхнул где-нибудь. В ночной свежести было что-то влажно-теплое. Тени от дерев и кустов, как кометы, острыми клинами падали на отлогую равнину. Такая была ночь, когда философ Хома Брут скакал с непонятным всадником на спине. Он чувствовал какое-то томительное, неприятное и вместе сладкое чувство, подступавшее к его сердцу. Он опустил голову вниз и видел, что трава, бывшая почти под ногами его, казалось, росла глубоко и далеко, и что сверх ее находилась прозрачная, как горный ключ, вода, и трава казалась дном какого-то светлого, прозрачного до самой глубины моря; по крайней мере он видел ясно, как он отражался в нем вместе с сидевшею на спине старухою. Он видел, как вместо месяца светило там какое-то солнце; он слышал, как голубые 
колокольчики, наклоняя свои головки, звенели. Он видел, как из-за осоки выплывала русалка, мелькала спина и нога, выпуклая, упругая, вся созданная из блеска и трепета» (Гоголь 2: 422).

Ф. Бэкон расценивал одоление Персеем Медузы в качестве аллегории «свержения тирании» (Бэкон 1972: 247), что в контексте Вия ассоциируется с тираноборческим пафосом избавления Хомой хутора от ведьмы, с тираноборческими мотивами, окружающими имя исторического Брута, убившего Юлия Цезаря. Хотя Хома в сцене избиения панночки защищает прежде всего себя, общесоциальный смысл его деяния очевиден. Власть ведьмы-панночки, дочери богатого сотника, почему-то считающего себя благочестивым, - не только социально-политическая, но, в главном, экзистенциально-антропологическая, это господство над человеком как видом, человеком как таковым.

Перед подвигом одоления Медузы Персей выкрал у ее сестер-грай принадлежащий им на троих глаз и зуб, вернув их им затем в обмен на сведения о стигийских нимфах, давших ему крылатые сандалии и шапку-невидимку. Граи - старухи, что корреспондирует одному из воплощений панночки. По поводу облика грай вновь обращает на себя внимание мотив зрения, зримости, столь значимый для Вия. Образ шапки-невидимки коррелирует с топикой зримости. Хома за очерченным им в церкви кругом, не глядящий на Вия, еще пока не видим им, т. е. словно в «шапке-невидимке». Фольклорносказочные мотивы, проявляющиеся в Bue (MOYLE 1979, Шульц 2017a), соотносятся с элементами сказочности в мифологеме о Персее: «освобождение царской дочери и награда» (MHМ 2: 305) - ср. мотив посмертной службы Хомы над умершей панночкой, что мнимо благочестивый отец-сотник в самоослеплении воспринимает в качестве пути к спасению ее души, обещая Хоме вознаграждение.

Из крови мертвой Медузы возник крылатый конь Пегас. Персей передвигался по воздуху с помощью крылатых сандалий, что делает его отчасти изоморфным Пегасу и сопоставимо с последующим эпизодом полета Хомы с ведьмой. В сцене полета Хома словно перенимает функции и Персея, и Пегаса. Образ птицы-тройки из поэмы Mертвые души созвучен образу летающего Пегаса: ведь благодаря последнему на реке Геликон выбит источник, «вода которого дарует вдохновение поэтам» (МНМ 2: 296). Связь фигуры Пегаса с идеей поэзии отзывается в эстетическом измерении образа птицытройки, его проецировании на автомифологию Гоголя-«поэта». Кроме того, Пегас после вознесения на Олимп «доставляет там громы и молнии Зевсу» (MHМ 2: 296) - ср. мотив молнии при описании птицы-тройки: «не молния ли это, сброшенная с неба?» (Гоголь 5: 239). Кроме того, мотив молнии в финале первого тома поэмы ассоциируется с Зевсом-Громовержцем и восточнославянским Перуном-громовержцем.

Персей в итоге осуществляет пророчество оракула об убийстве им своего деда - Акрисия. Здесь возникают косвенные аллюзии на миф об Эдипе, невольно убившем своего отца. В данном случае убитый дед Акрисий «замещает» фигуру отца Персея. 
И. П. Смирнов связывал мотивы эдипальности с реализмом (Смирнов 1994: 81-130), но Вий демонстрирует, что и романтизм не чужд им - как, впрочем, и всякий другой художественный стиль. «Эдипальные» параллели к персонажам Вия возможны также на основе мотива слепоты Эдипа, выколовшего себе глаза после узнания правды о своих проступках.

По замечанию С. С. Аверинцева, в древнегреческой традиции знание связывается с глазами, а умозрение - с телесным зрением: «обманутый очевидностью и прозревший незримое, Эдип выкалывает глаза, которые его предают. Его знание обращается на него самого, его зрение обращается вовнутрь»; «Мудрость-сила, мудрость-власть - это вина и слепота» (АвЕРинцев 1972: 100-101). Аналог исторической легенды для Эдипа-слепец Демокрит: этот философ выжег себе глаза, чтобы яснее видеть невидимое (АвЕРинцев 1972: 102).

Ф. Ницше отметил в истории Эдипа (отраженной в трагедии Софокла) торжество эстетического подхода к жизни и эстетического оправдания жизни (см. Ницше 1990). У Гоголя черты сходного эстетизма проявляются через описание необычного видения, открывшегося Хоме в сцене полета с ведьмой, через «обыскусствовление» карнавальных мотивов «киевской» повествовательной линии Вия. Благодаря этому карнавальные мотивы предстают не только в свой непосредственной функции серьезно-смехового, но также символизируют начало по-высокому вымышленной (т. е. хотя и ирреальной, но все же по-своему действительной) фикциональности: превращают «льющуюся через край жизнь» школяров (и не только их) в факт искусства.

В Вие изображены, с одной стороны, слепота «начальника гномов» (Гоголь 2: 414), призывающего поднять ему веки, и, с другой, «прозрение» в суть вещей мира, «новое видение» Хомы во время его полета с ведьмой, словно зачеркивающие предыдущий опыт героя в качестве «неполного зрения». В описании «прозрения» Хомы - аналог смотрения Каином неведомых миров во время его полета с Люцифером в мистерии Дж. Г. Байрона Каин. Что касается факта Виевой незрячести, то он сближен Гоголем с инфернальностью как неполнотой, отпадением от Абсолюта.

К гоголевскому герою новое видение приходит после совершенного им невольного прегрешения (полет с панночкой) - так и Эдип прозрел лишь после своих невольных проступков. Когда Хома оглядывается на Вия (смотрит на него - «познает», если в древнегреческой традиции) - это выглядит как уступка эллинскому язычеству, и здесь Хома уклоняется от христианских начал. «Побеждая чудовище, Эдип сам становится чудовищем» (АвЕРинцев 1972: 98) - так и одолевший ведьму Хома невольно «хтонизируется» в финальном эпизоде, когда он все-таки оглядывается и смотрит (вопреки собственному внутреннему голосу).

\footnotetext{
${ }^{3}$ Аверинцев также имеет в виду, что знание-«сила» и знание-«власть»- нечто негативное (оно ассоциируется с неким самоутверждением, подавлением другого). Такая оценка распространяется им на «внешние» виды знания и «зрения». «Внутреннее» же знание (соответственно внутреннее зрение) - уже позитивный момент.
} 
В мифологии хтонические существа всегда имеют какую-либо телесную мутацию, телесные изъяны (один глаз и один зуб на трех грай; змеи вместо волос у Медузы Горгоны и т. п.) - отражение их ущербной пространственности в целом, что находит продолжение в их претензиях на охват и завладение внеэнтропийным, позитивным пространством (Евзлин 1993b: 312-313, 319). В таком контексте финальная слепота Эдипа - фактор его «хтонизации», делания его монструозным. Слепой Вий и остальные чудовища, ведьма в ипостаси старухи - все это хтонизированные существа; мотив эдипальности в своем измерении слепоты представлен тут отрицательно. Когда Хома на основе «поперечивающего чувства» оглядывается и смотрит, то это прибегание к помощи внешнего зрения символизирует отсутствие у него зрения внутреннего, которое все же получил ослепивший себя Эдип и которое одно могло бы помочь Хоме выстоять в поединке.

Тот факт, что в финале гоголевской повести хуторская церковь вообще остается полностью заброшенной, так, что никто не найдет к ней дороги, свидетельствует об одолении хтоническим деформированным пространством пространства позитивного, сакрального.

В мифе об Эдипе значима роль символики числа «три»: именно на перекрестке трех дорог встречает Эдип своего отца Лая. Такой перекресток считался полем потенциально опасного выбора, понятого мистически - ср. в Вие мотив триады ночей, во время которых Хома должен совершать таинства, одновременно подвергаясь испытанию или мотив трех хуторских помощников, приставляемых к нему сотником. ${ }^{4}$

Выколовший себе глаза после узнания страшной правды о себе, Эдип «в сопровождении своей верной дочери Антигоны [...] пришел в Колон [...], где эринии, у которых была в этом городе священная роща, затравили его до смерти, и Тесей похоронил тело там, где в Афинах хоронили святых» (ГРейвс 1992: 282). Мифологические эринии - старухи, что коррелирует с одним из хтонических воплощений панночки, тем самым сближаемой с богинями мести, наказания и угрызений совести. Тут эксплицируется указание на «прегрешение», «вину» Хомы. Впрочем, факт итогового признания Эдипа «святым» отражается на потенциальной христианской семантике образа Хомы как мученика и страстотерпца.

По замечанию В. П. Стратиловой, «особенность страдания у Софокла заключается в том, что с ним связано самораскрытие образа» Эдипа, что, в свою очередь, соотнесено с идеей самоПознания (СтРАТиловА 1975: 23). В период второго пребывания на хуторе панночки аффект Хомы становится уже почти полностью негативным. Мотивы упоения Хомы красотой мертвой панночки (в чем эстетизм героя и частичный эстетизм его оценки автором / повествователем) лишь оттеняют мрачность его роли мученика. Вполне ли самораскрывается в этих сценах образ гоголевского протагониста? Прямое самораскрытие отсутствует. Заданы элементы самораскрытия косвенного -

${ }^{4}$ О значимости числа «три» в Вие см. АРВАТ 2000. 
через мотив испытания прежде всего. По существу же, самораскрывает Хому только его смерть. Как бы Хома ни избегал худшего, он был готов к нему (к «обреченности», «любви к судьбе»). Хома погибает, но душа его спасена (Фомичев 1995-1996), а хутор и окрестности Киева избавлены от ведьмы.

В. Н. Ярхо обнаруживает в образе Эдипа «трагедию разума»: первоначальное знание героя оказывается «иллюзорно, ошибочно» (Ярхо 1978: 217). Так же и иллюзии Хомы относительно того, что он «три ночи как-нибудь» «отработает», ${ }^{5}$ а зато «сотник набьет его карманы золотом» (Гоголь 2: 433), полностью разбиваются. По замечанию В. П. Стратиловой, Эдип стремился «овладеть тайной божества, [...] высшей мудростью» (СтРАТиловА 1975: 30) - и в этом, добавим, он проявляет себя как «философ», причем религиозного типа.

В сценах второго пребывания на хуторе Хома стремится понять тайну панночки, внутренне и внешне разглядеть ее истинные черты, опознать их то ли как инфернальные, то ли как благие. Однако Хоме так и не удается отделить в панночке одно от другого: инфернальное от благого. В этом преимущественный эстетизм его оценок, заставляющий снять этические критерии при восприятии событийной канвы повести. Может показаться, что, в отличие от Эдипа, Хома достигает мудрости не «высшей», но относительной. В чем было бы сходство Хомы с булгаковским Мастером, заслужившим не «свет», но «покой».

Однако в качестве победителя ведьмы, избавителя людей от ее чар и страстотерпца Хома - христианский подвижник. Вот в таком аспекте Хома уже ближе к фигуре Эдипа. На фоне христианских параллелей второе пребывание Хомы на хуторе становится словно его вторым пришествием, символически сопоставимым с ожидаемым вторым пришествием Того, Который грядет постоянно.

Экстраполируя христианские подходы к фигуре Эдипа и отрицая значимость идеи рока для древнегреческой трагедии, Вяч. И. Иванов глубоко писал о том, что наряду со скорбью у Софокла дана «всепобеждающая ясность», «солнечная жизнерадостность» (ИвАнов 2010: 130-131). Разве не та же оценка (с добавлением комически-карнавальных обертонов) применима в отношении пафоса Вия, особенно финала повести - беседы двух школяров после гибели Хомы?

К мотиву «неполного зрения» относится также эпизод практически постепенного узнавания Хомой мертвой ведьмы после его беседы с сотником: «Он приблизился и, еще раз откашлявшись, принялся читать, не обращая никакого внимания на сторону и не решаясь взглянуть в лицо умершей. Глубокая тишина воцарилась. Он заметил, что сотник вышел. Медленно поворотил он голову, чтобы взглянуть на умершую и... Трепет побежал по его жилам;

${ }^{5}$ Слово «отработает» звучит в данном случае в виде указания на избавление от некоего непосильного, но также странного, непонятного бремени и, вместе с тем, в виде указания на нежеланную, но почему-то покорную готовность нести его по принципу «авось». 
пред ним лежала красавица, какая когда-либо бывала на земле. Казалось, никогда еще черты лица не были образованы в такой резкой и вместе гармонической красоте. Она лежала как живая. Чело прекрасное, нежное как снег, как серебро, казалось, мыслило; брови - ночь среди солнечного дня, тонкие, ровные, горделиво приподнялись над закрытыми глазами, а ресницы, упавшие стрелами на щеки, пылавшие жаром тайных желаний; уста - рубины, готовые усмехнуться... Но в них же, в тех же самых чертах, он видел что-то страшно-пронзительное. Он чувствовал, что душа его начинала как-то болезненно ныть, как будто бы вдруг среди вихря веселья и закружившейся толпы запел кто-нибудь песню об угнетенном народе. Рубины уст ее, казалось, прикипали кровию к самому сердцу. Вдруг что-то страшно-знакомое показалось в лице ее. „Ведьма!“‘ вскрикнул он не своим голосом, отвел глаза в сторону, побледнел весь и стал читать свои молитвы; это была та самая ведьма, которую убил он» (Гоголь 2: 433).

Примечательно, что в редакции Вия 1835 г. Хома сначала вообще не узнавал ведьму, благодаря чему мотив проблематизации видения заострялся.

Мертвая панночка в церкви также незряча, с трудом пытается опознать Хому: «Она идет прямо к нему. В страхе очертил он около себя круг. С усилием начал читать молитвы и произносить заклинания, которым научил его один монах, видевший всю жизнь свою ведьм и нечистых духов. Она стала почти на самой черте; но видно было, что не имела сил переступить ее, и вся посинела, как человек, уже несколько дней умерший. Хома не имел духа взглянуть на нее. Она была страшна. Она ударила зубами в зубы и открыла мертвые глаза свои. Но не видя ничего, с бешенством - что выразило ее задрожавшее лицо - обратилась в другую сторону и, распростерши руки, обхватывала ими каждый столп и угол, стараясь поймать Хому. Наконец остановилась, погрозив пальцем, и легла в свой гроб» (Гоголь 2: 440-441).

Поразительным моментом в повести является тот, где летающий гроб с панночкой «крестит» воздух вокруг себя: «Философ всё еще не мог прийти в себя и со страхом поглядывал на это тесное жилище ведьмы. Наконец гроб вдруг сорвался с своего места и со свистом начал летать по всей церкви, крестя во всех направлениях воздух. Философ видел его почти над головою, но вместе с тем видел, что он не мог зацепить круга, им очерченного, и усилил свои заклинания» (Гоголь 2: 441).

Крещение воздуха гробом, в котором - представительница инфернальной стихии, объяснимо лишь сложной и двусмысленной контаминацией в повести христианских и языческих черт как, с одной стороны, противостоящих друг другу, a, с другой, неожиданно коррелирующих. Высказанное Е. М. Мелетинским мнение о том, что ведьма вообще (конкретно Вий не имелся им в виду) выступает в виде реликта языческой Великой матери матриархальной эпохи, отрицательно переосмысленного в эпоху патриархата (МЕЛЕТинский 1994: 76), косвенно подтверждается незрячестью мертвой панночки и призываемой ею дьявольщины. Ведь могущественная Великая мать - атрибут матриархата - зачастую воображалась безглазой (ГолАн 1993: 165). 
Мотивы древнегреческой (и вообще языческой) мифологии, в самом деле, тесно сплетены в повести Гоголя с мотивами христианскими, чем образован неповторимый духовно-эстетический синтез Вия.

\section{Литература}

АВЕРИНцЕВ 1972 = АвеРИнцЕВ С. С. К истолкованию символики мифа об Эдипе. В кн.: Античность и современность. Москва, 1972. 90-102.

АРАБОВ 1998 = АРАБОВ Ю. Полет ГоГоЛЯ. Искусство кино 1998/11: 103-120.

АРват 2000 = АрвАт Н. Н. О троичности в повести Гоголя «Вий». Гоголезнавчі студії. Гоголеведческие студии. Вип. 5. Ніжин, 2000. 109-121.

Бруно 1999a = Бруно Дж. Изгнание торжествующего зверя. В кн.: Бруно Дж. Изгнание торжествующего зверя. О причине, начале и едином. Минск, 1999. 3-260.

Бруно $1999 \mathrm{~b}=$ Бруно Дж. О причине, начале и едином. В кн.: Бруно Дж. Изгнание торжествующего зверя. О причине, начале и едином. Минск, 1999. 261-428.

Бэкон 1972 = Бэкон Ф. О мудрости древних. В кн.: Бэкон Ф. Сочинения в 2 томах. Т. 2. Москва, 1972. 223-301.

ВАйСКоПФ 1993 = ВАЙскоПФ М. Сюжет Гоголя. Москва, 1993.

Гоголь $=$ Гоголь Н. В. Полное собрание сочинений и писем в 17 томах. Москва-Киев, 2009-2010.

ГолАн 1993 = ГолАн А. Миф и символ. Москва, 1993.

ГРейвС 1992 = ГрейвС Р. Мифология Древней Грещии. Москва, 1992.

ДЕЛЕЗ-ГВАТТАРИ 2009 = ДЕЛЕЗ Ж., ГВАТТАРИ Ф. Что такое философия? Москва, 2009.

Евзлин 1993а = Евзлин М. Мифологическая структура преступления и безумия в повести Пушкина «Пиковая дама». В кн.: Евзлин М. Космогония и ритуал. Москва, 1993. 31-55.

Евзлин $1993 \mathrm{~b}=$ Евзлин М. Персей и Горгоны. В кн.: Евзлин М. Космогония и ритуал. Москва, 1993. 301-334.

ИвАнов $2010=$ ИвАнов Вяч. И. Человек и судьба в трагедиях Эсхила и Софокла. В кн.: Античность и культура Серебряного века. К 85-летию А. А. Тахо-Годи. Москва, 2010. 130-131.

Ильин 2000 = Ильин В. Н. Миросозериание графа Л. Н. Толстого. Санкт-Петербург, 2000.

ИчиРО 1989 = ИчиРо И. Общеславянский фольклорный источник гоголевского Вия. Известия АН СССР 1989/5: 454-459.

Киченко 2008 = Киченко А. С. Творчество как мифотворчество. Горловка, 2008.

ЛЕВКИЕВСКАЯ 1998 = ЛЕВКИЕВСКАЯ Е. Е. К воПросУ об одной мистифиКации или гоголевский Вий при свете украинской мифологии. Studia Mythologica Slavica 1. Ljubljana, 1998. 307-316.

МЕЛЕтинСкий 1994 = МЕлЕтинский Е. М. О литературных архетипах. Москва, 1994.

МНМ = ТоКАРЕВ С. А. (ред.) Мифы народов мира. Т. 1-2. Москва, 1991-1992.

Ницше 1990 = Ницше Ф. Рождение трагедии из духа музыки. В кн.: Ницше Ф. Сочинения в 2 томах. Т. 1. Москва, 1990. 47-157.

СмиРнов 1994 = СмиРнов И. П. Психодиахронологика. Психоистория русской литературы от романтизма до наших дней. Москва, 1994.

СофроновА $2010=$ СофроновА Л. А. Мифопоэтика раннего Гоголя. Санкт-Петербург, 2010. 
СТРАТИЛОВА 1975 = СТРАТИЛОВА В. П. Царь Эдип и тема Эдипа в творчестве Софокла. Москва, 1975.

ТопоРов 1993 = ТопоРов В. Н. Эней-человек судьбы. $K$ «средиземноморской» персонологии. Ч. 1. Москва, 1993.

Фомичев 1995-1996 = Фомичев С. А. Повесть Н. В. Гоголя «Вий». Заметки комментатора. В кн.: Новые безделки. Сборник статей к 60-летию В. Э. Вачуро. Москва, 1995-1996. 441-443.

ШЕЛлинг 2013 = ШЕЛлинг Ф. В. Й. Философия мифологии. Т. 1-2. Санкт-Петербург, 2013.

Шульц $1998=$ Шульц С. А. Мифологизм Гоголя. АКД. Москва, 1998.

Шульц $2000=$ Шульц С. А. Культурно-мифологическая семантика образа пасичника Рудого Паньки в «Вечерах на хуторе близ Диканьки» и в «Миргороде». Studia Litteraria Polono-Slavica 5. Warszawa, 2000. 147-161.

Шульц $2017 \mathrm{a}=$ Шульц С. А. Мотивы русской волшебной и бытовой сказки в повести Гоголя «Вий». Wiener Slawistischer Almanach 79 (2017): 155-164.

Шульц $2017 \mathrm{~b}=$ Шульц С. А. Пушкин - Гоголь: к метафизике внутреннего диалога. Гоголезнавчі студії. Гоголеведческие студии. Вип. 23. Ніжин, 2017. 139-162.

Ярхо 1978 = Ярхо В. Н. Драматургия Эсхила и некоторые проблемы древнегреческой трагедии. Москва, 1978.

Moyle $1979=$ Moyle N. K. Folktale Patterns in Gogol's Vij. Russian Literature 7 (1979): $665-688$.

SoBEL 1979 = SoBel R. Gogol's Vij. Russian Literature 7 (1979): 565-584.

\author{
SERGEI SHUL'TS \\ independent researcher
}

\title{
The Motives of Ancient Greek Mythology in Gogol's Story Vij
}

The facts of Gogol's appeal to the models of classical forms of myth and ritual are interesting not only by themselves but also in the aspect of their relationship with the arsenal of Christian mythology. The fundamental point here is that in light of the historical interpretation of the myth and the Revelation by F. W. J. Schelling, the mythology since its initial stage organically developed to Christianity, to the truths of Revelation (as the historical movement "flowed" into them).

The symbolic complex of the story $V i j$, interlacing with Eros and Thanatos, allows parallels to the myth of Orpheus and Eurydice since in the case of the story Vij and in the case of myth, the motive of prohibition on sight also holds. The philosopher (i.e. the poet in the archaic and romantic notion) Homa Brut comes into contact with the world of death not of his own free will, besides, the panicle Eurydice died because of him. Orpheus partakes of the Dionysian sacraments. A visit to Orpheus of hell equated him, in Christian understanding, with Christ. In Gogol's story Vij, Dionysus and Christ have implicitly come together.

The motive of the story $V i j$ for blindness is related to Oedipus's self-blindness motive. Mythological Erinnes, persecuted by Oedipus, are old women, which correlates with one of the chthonic incarnations of the plaque, thereby drawing closer to the goddesses of revenge, punishment, and remorse of conscience. The fact of the final recognition of Oedipus 
as "holy" is reflected in the potential Christian semantics of the image of Homa as a martyr and passion-bearer.

As the winner of the witch, the deliverer of people from her misfortunes and the passion bearer Homa is a Christian ascetic. Against the background of Christian parallels, the second stay of Homa on the farm becomes as if his "second coming", symbolically comparable to the expected second coming of Christ, who is coming all the time.

The terrible glance of $V i j$ and pannochka certainly reminds of the slaying glance of Medusa Gorgon, which forced all living things to petrify.

There is pathos of fighting tyranny in ridding the farm from the witch by Homa. Although Homa defends himself first of all in the beating scene, the general social meaning of his action is obvious. The power of the pannochka (she is the daughter of a wealthy sotnik), who for some reason considers himself pious, is not only socio-political but, in the main, existential-anthropological, this domination over man as a species, over man as such.

The motives of ancient Greek and in general pagan mythology are closely intertwined in Gogol's story with Christian motives, which formed the unique spiritual and aesthetic synthesis of the story $V i j$.

Keywords: Gogol, ancient Greek mythology, pagan and Christian motives, Orpheus and Eurydice, Eros and Thanatos 